\title{
RISK RETURN ANALYSIS OF NSE LISTED STOCKS
}

\author{
NARAYAN GAONKAR \\ Research Scholar, \\ AIET, Mijar, Moodbidri. 574225 \\ Dr. KUSHALAPPA. S \\ Senior Assistant Professor, \\ AIET, Mijar, Moodbidri. 574225
}

\begin{abstract}
:
Risk and return are the two important factors which will have an impact on the investment decision. One can't talk about investment return without talking about risk because investment decisions invariably involve a tradeoff between the two. Risk refers to the possibility that the actual outcome of an investment will differ from its expected outcome. More specifically, most investors are concerned about the actual outcome being less than the expected outcome as the wider the range of possible outcomes, the greater the risks. Almost everyone recognizes that risk must be considered in determining value and making investment choices. In fact, valuation and an understanding of the tradeoff between risk and return form the foundation for maximizing share holder wealth. The study is undertaken with the main objective of determining the risk return profile of 30 stocks listed on NSE. Only 30 top companies shares listed on NSE are considered in this paper.
\end{abstract}

KEY WORDS: Portfolio, return, risk.

\section{INTRODUCTION:}

Every investment is characterized by risk and return. Risk is a situation involving explore to uncertainty. When an investor deploys his fund into some securities, he/she does so after analyzing the expected return. If actual return obtained is the same as the expected return, such an investment considered to be risk free i.e. an investment with no risk. Usually, higher the risk higher the return, lower the risk lower the return. However, a general understanding of this phenomenon is not sufficient to make appropriate decisions relating to investments. A more quantifiable analysis is required to understand investments better. The quantifiable analysis is done by use of simple arithmetic and statistics to analyses the relationship. Risk is defined as the chance that an investment's actual return will be different than expected. This includes the possibility of losing some or all of the original investment.

Those of us who work hard for every penny we earn have a hard time parting with money. Therefore, people with less disposable income tend to be, by necessity, more risk averse. On the other end of the spectrum, day traders feel that if they aren't making dozens of trades a day, there is a problem. These people are risk lovers.

\section{OBJECTIVES:}

The core objective of this study is to analyze the risk and return of 30 top stocks listed on NSE. However in order to achieve the main objective, the following specific objectives have been framed:

To study the variation in the stock returns for the study period of one years. 


\section{Asia Pacific Journals}

To rank the companies on the basis of return and risk

To find out the risk and return of portfolio consisting of 30 stocks and compare it with risk and return of individual stock.

To offer meaningful suggestions to the investors based on the findings of the study.

\section{METHODOLOGY:}

The study is purely based on secondary data collected from NSE Web Site and Money Control.com. The monthly share prices of 30 top companies listed on NSE, which are used to compile NSE NIFTY, are collected from March 2013 to March 2014. These data are used to calculate actual return, CAPM return and abnormal return of each of the 30 companies. Then, 30 companies are ranked according to the returns yielded by them. Standard deviations and coefficient of variation of these 30 companies are arrived at to rank them on the basis of risk. This information is presented through tables.

\section{TECHNIQUES OF ANALYSIS:}

\section{Actual Return}

Actual returns for each company has been computed for the study period as under

$$
r_{i}=\frac{p_{1}-p_{0}}{p_{0}}
$$

Where, $r_{i}$ is return on individual security, $\mathrm{P}_{1}=$ Market price (closing) of security and $\mathrm{P}_{0}=$ Market price of security on day ( $\left.\mathrm{t}-1\right)$. Comparatively, the actual returns for the market are also computed as:

$$
\mathbf{r}_{\mathbf{m}}=\frac{\mathbf{P}_{\mathbf{1}}-\mathbf{P}_{\mathbf{0}}}{\mathbf{P}_{\mathbf{0}}}
$$

Where $r_{m}$ is return on market, $P_{1}$ is closing market return and $\mathrm{P}_{0}$ market return in the beginning

In the next step, average actual returns of individual stocks and market return is computed

\section{CAPM Return}

CAPM return is calculated by applying the following formulae

$$
\mathbf{r}_{\mathbf{i}}=\mathbf{R}_{\mathbf{f}}+\boldsymbol{\beta}_{\mathbf{i}}\left(\mathbf{R}_{\mathbf{m}}-\mathbf{R}_{\mathbf{f}}\right)
$$

Where, $\mathbf{R}_{\mathbf{f}}=$ Risk free rate, $\mathbf{R}_{\mathbf{m}}=$ return on market, $\boldsymbol{\beta}_{\mathbf{i}}=$ beta of individual security and $\mathbf{r}_{\mathbf{i}}$ is return on individual security.

Beta of the security is calculated with the help of the following formula

$$
\beta_{\mathbf{i}}=\mathbf{r} \frac{\sigma_{\mathbf{i}}}{\sigma_{\mathrm{m}}}
$$

Here, $\mathbf{r}$ is correlation between individual security return and market return, $\boldsymbol{\sigma}_{\mathbf{i}}$ is standard deviation of individual security and $\boldsymbol{\sigma}_{\mathbf{m}}$ is standard deviation of market return.
Abnormal returns
Abnormal return is the excess of the actual return over the expected return. It is calculated as under 


\section{Abnormal Return = Actual Return - CAPM Return}

Then, companies are ranked according to actual, CAPM and abnormal returns.

\section{Standard deviation}

It measures the amount of variation from the average. A low standard deviation indicates that the data points tend to be very close to the mean (also called expected value); a high standard deviation indicates that the data points are spread out over a large range of values.

$$
\begin{gathered}
\text { S.D. }=\sqrt{\frac{\Sigma \mathrm{x}^{2}}{\mathbf{n}}} \\
\text { Where: } \begin{aligned}
\Sigma \mathrm{x}^{2}= & \begin{array}{l}
\text { The sum of the sauares of the differences between } \\
\text { the Mean and each score }
\end{array} \\
\mathbf{n} & =\text { The number of scores }
\end{aligned}
\end{gathered}
$$

\section{Coefficient of variation}

The coefficient of variation represents the ratio of the standard deviation to the mean, and it is a useful statistic for comparing the degree of variation from one data series to another, even if the means are drastically different from each other.

\section{Coefficient of Standard Deviation \\ Variation $=$ \\ Expected Return}

\section{ANALYSIS AND DISCUSSION}

As per Table No.1; HCL Tech has the highest actual returns and abnormal returns. Lupin Ltd. ranked second and DR Reddy laboratories third and INFOSYS ranked fourth in terms of actual return. Axis Bank has the highest CAPM return. IDFC Bank has the second highest CAPM return. Bank of Baroda and Asian Paint attained fourth position in terms of CAPM return. Lupin Ltd has the second highest abnormal returns.

Asian Paint, DLF, Jindal steel, IDFC have the least Actual Returns respectively. The CAPM Returns of HCL Tech, Infosys, CAIRN and Lupin Ltd are very low. The HCL Tech have high expected return on same time it have very less CAPM return because of high risk involved in the stock.

Table No.1: Rank of the NSE 30 Companies according to Actual, CAPM and Abnormal Return

\begin{tabular}{|l|l|l|l|l|l|l|l|}
\hline SL.NO & COMPANY NAME & $\begin{array}{l}\text { ACTUAL } \\
\text { RETURN }\end{array}$ & RANK & $\begin{array}{l}\text { CAPM } \\
\text { RETURN }\end{array}$ & RANK & $\begin{array}{l}\text { ABNORAL } \\
\text { RETURN }\end{array}$ & RANK \\
\hline 1 & ACC & -0.77177074 & 22 & 0.913640274 & 11 & -1.685411014 & 21 \\
\hline 2 & AMBUJA CEM & -0.910725222 & 23 & 0.841796613 & 19 & -1.752521835 & 23 \\
\hline 3 & ASIAN PAINT & -7.094725502 & 30 & 1.049909329 & 4 & -8.144634831 & 30 \\
\hline 4 & AXIS BANK & 0.476337556 & 15 & 1.113694681 & 1 & -0.637357125 & 17 \\
\hline 5 & BAJAJ-AUTO & -0.172658716 & 18 & 0.838142362 & 20 & -1.010801078 & 18 \\
\hline
\end{tabular}


Asia Pacific Journals

\begin{tabular}{|c|c|c|c|c|c|c|c|}
\hline 6 & BANK of BARODA & -1.398478273 & 25 & 1.049541255 & 3 & -2.448019528 & 25 \\
\hline 7 & BHARTI ARTL & -0.184718305 & 19 & 0.903092944 & 13 & -1.087811249 & 19 \\
\hline 8 & BHEL & -0.766738079 & 21 & 0.934631951 & 10 & -1.701370029 & 22 \\
\hline 9 & BCPL & 0.315739402 & 17 & 0.937163608 & 9 & -0.621424206 & 16 \\
\hline 10 & CAIRN & 1.011274153 & 8 & 0.736622272 & 27 & 0.274651881 & 8 \\
\hline 11 & CIPLA & 0.438512823 & 16 & 0.710030317 & 28 & -0.271517494 & 13 \\
\hline 12 & COAL INDIA & -1.759205634 & 26 & 0.886276699 & 15 & -2.645482333 & 26 \\
\hline 13 & DLF & -4.314195598 & 29 & 0.982233547 & 8 & -5.296429145 & 29 \\
\hline 14 & DR REDDY & 4.402523386 & 3 & 0.789698547 & 22 & 3.612824838 & 3 \\
\hline 15 & GAIL & 1.146509432 & 6 & 0.842868941 & 18 & 0.303640491 & 7 \\
\hline 16 & GRASIM & -1.017999629 & 24 & 0.911081639 & 12 & -1.929081269 & 24 \\
\hline 17 & HCL TECH & 7.01851448 & 1 & 0.641692288 & 30 & 6.376822193 & 1 \\
\hline 18 & HDFC & 0.631501976 & 11 & 0.870470348 & 17 & -0.238968372 & 11 \\
\hline 19 & HDFC BANK & 0.807450103 & 10 & 0.896688479 & 14 & -0.089238376 & 10 \\
\hline 20 & HERO MOTOCORP & 1.649256631 & 5 & 0.747012153 & 25 & 0.902244478 & 5 \\
\hline 21 & HINDALCO & 0.816266249 & 9 & 0.770024477 & 23 & 0.046241772 & 9 \\
\hline 22 & ICICI BANK & 0.506307839 & 13 & 1.045727243 & 5 & -0.539419405 & 15 \\
\hline 23 & IDFC & -2.819879848 & 27 & 1.057739633 & 2 & -3.877619481 & 28 \\
\hline 24 & INDUSIND BANK & 0.493733731 & 14 & 0.998167221 & 7 & -0.50443349 & 14 \\
\hline 25 & INFOSYS & 2.758394289 & 4 & 0.684721223 & 29 & 2.073673065 & 4 \\
\hline 26 & ITC & 1.130500955 & 7 & 0.805273922 & 21 & 0.325227034 & 6 \\
\hline 27 & JINDAL STEL & -2.87541528 & 28 & 0.75967123 & 24 & -3.63508651 & 27 \\
\hline 28 & KOTAK BANK & 0.615449912 & 12 & 0.876994371 & 16 & -0.261544459 & 12 \\
\hline 29 & $\begin{array}{ll}\text { LARSEN } & \text { AND } \\
\text { TOUBRO } & \end{array}$ & -0.516362405 & 20 & 1.03995941 & 6 & -1.556321815 & 20 \\
\hline 30 & LUPIN LTD & 4.915486142 & 2 & 0.745 & 26 & 4.170486142 & 2 \\
\hline
\end{tabular}

Source: Authors Compilation

Table No.2: Rank of the NSE 30 Companies according to Standard deviation and Coefficient of variation

\begin{tabular}{|l|l|l|l|l|}
\hline SL.NO & COMPANY NAME & STANDARD DEVIATION & CO EFFICIENT VARIANCE & RANK \\
\hline 1 & ACC & 8.838410301 & -11.45211893 & 5 \\
\hline 2 & AMBUJA CEM & 6.792085151 & -7.457886291 & 8 \\
\hline 3 & ASIAN PAINT & 27.46005231 & -3.870488338 & 11 \\
\hline 4 & AXIS BANK & 15.36720169 & 32.26115916 & 29 \\
\hline
\end{tabular}


Asia Pacific Journals

\begin{tabular}{|c|c|c|c|c|}
\hline 5 & BAJAJ-AUTO & 6.054246486 & -35.06481812 & 2 \\
\hline 6 & BANK of BARODA & 12.49736167 & -8.93640031 & 6 \\
\hline 7 & BHARTI ARTL & 10.24649009 & -55.47089712 & 1 \\
\hline 8 & BHEL & \begin{tabular}{|l|}
12.25647184 \\
\end{tabular} & -15.98521344 & 4 \\
\hline 9 & BCPL & 10.30618006 & 32.64141244 & 30 \\
\hline 10 & CAIRN & 6.081801655 & 6.013998911 & 20 \\
\hline 11 & CIPLA & 5.165159082 & 11.77880967 & 25 \\
\hline 12 & COAL INDIA & 8.413136139 & -4.782349475 & 9 \\
\hline 13 & DLF & 11.5890396 & -2.686257342 & 13 \\
\hline 14 & DR REDDY & 4.255495403 & 0.966603702 & 14 \\
\hline 15 & GAIL & 6.960317327 & 6.07087664 & 21 \\
\hline 16 & \begin{tabular}{|l} 
GRASIM \\
\end{tabular} & \begin{tabular}{|l|}
7.952964083 \\
\end{tabular} & -7.812344772 & 7 \\
\hline 17 & HCL TECH & 8.384379598 & 1.194608862 & 15 \\
\hline 18 & HDFC & 6.497956918 & 10.2896858 & 24 \\
\hline 19 & HDFC BANK & 6.675639888 & 8.267557173 & 22 \\
\hline 20 & HERO MOTOCORP & 5.949348796 & 3.607291118 & 18 \\
\hline 21 & HINDALCO & 8.046257715 & 9.857393622 & 23 \\
\hline 22 & ICICI BANK & 11.77845801 & 23.26343206 & 28 \\
\hline 23 & IDFC & 12.69225707 & -4.500992154 & 10 \\
\hline 24 & INDUSIND BANK & 11.22659332 & 22.73815342 & 27 \\
\hline 25 & INFOSYS & 9.748294722 & 3.534046877 & 17 \\
\hline 26 & ITC & 5.607773766 & 4.960432576 & 19 \\
\hline 27 & JINDAL STEL & \begin{tabular}{|l|}
9.474572962 \\
\end{tabular} & -3.295027688 & 12 \\
\hline 28 & KOTAK BANK & 7.323160284 & 11.8988729 & 26 \\
\hline 29 & $\begin{array}{l}\text { LARSEN } \\
\text { TOUBRO }\end{array}$ & 16.1690094 & -31.3132971 & 3 \\
\hline 30 & LUPIN LTD & \begin{tabular}{|l|}
7.147971949 \\
\end{tabular} & 1.45417396 & 16 \\
\hline
\end{tabular}

\section{Source: Authors Compilation}

Table 2 shows that Bharti Airtel, Bajaj Auto, Larsen and Toubro having less coefficient of variation due to low volatility in the stock returns ranked first, second and third. BCPL ranked least as it has highest rate of volatility. Axis Bank and ICICI
Bank are also having less coefficient of variation.

\section{FINDINGS:}

This part of the study speaks about the major findings of the study 
- It is clear from the study that HCL Tech has the highest actual returns and abnormal returns.

- It is found in the study that Asian Paint has the least actual returns

- The study reveals the fact that the CAPM return of HCL Tech is the least.

- It is crystal clear from the study that BPCL has the least abnormal returns.

- It is evidence from the study that Hero Motocorp has the least systematic risk,

- It is clear from the study that ICICI Bank has the least unsystematic risk.

- The study shows that Total risk of Dr. Reddy laboratories is the least.

- It is fact from the study that the systematic risk of Axis Bank is the highest

- It is found in the study that Asian Paint has the highest unsystematic risk and total risk

- The study shows that out of 30 stocks, 13 stocks have returns less than the portfolio returns and the most of the stocks have returns higher than the portfolio return.

\section{CONCLUSION}

The study risk return analysis helps the investor to pick up the securities based on his choice. The study of this kind provides information about the performance of various stocks in the market in terms of risk and return. A stock with more systematic risk is not favourable for investment due to the reason that it has highest market risk, which cannot be diversified like unsystematic risk. Thus to construct an efficient portfolio, it is better to avoid such stocks. The study does not suggest the universal best or worst stocks for investment, because ratings of the stocks must be based on the type of investment and the type of investor. An investor who is ready to bear high risk but expect high return will go such stocks where risk and returns are high. Whereas an investor with less risk bearing capacity will go for those stocks where the risk and return are low. Among the stocks under study HCL Tech has the highest actual returns and abnormal returns and therefore better for those investors whose objective of investment is to maximize the returns. A risk adverse investor can prefer Dr. Reddy's stocks as it has the lowest risk compared to all other stocks under study. 
Asia Pacific Journals

\section{BIBLIOGRAPHY}

[1] Balla V. K. (2002), Portfolio Analysis and Management, Sulthan Chand and Co. Ltd., New Delhi.

[2] BhatSudhindra (2008), Security Analysis and Portfolio Management, Excel Books, New Delhi.

[3] Booie.Zvi, Kane Alex and et.al.(2006), Investments, $6^{\text {th }}$ edition, Tata McGraw Hill, New Delhi.

[4] Chandra Prasanna (2008), Investment Analysis and Portfolio Management, $3^{\text {rd }}$ edition, Tata McGraw Hill, New Dehi.

[5] Fisher. E. Donald and Jordan. J. Ronald (2006), Security Analysis and Portfolio Management, Pearson Prentice Hall.

[6] Kevin. S (2008), Portfolio Management, $2^{\text {rd }}$ edition, PHI Learning Pvt. Ltd, New Delhi.

[7] PandianPunithavathy (2004), Security Analysis and Portfolio Management, Vikas Publishing House Pvt. Ltd, New Delhi.

[8] Reilly. K. Frank and Brown. C. Keith (2006), Investment Analysis and Portfolio Management, $8^{\text {rd }}$ edition, Cengage Learning India Pvt. Ltd, New Delhi. 